OPEN ACCESS

Approved by:

Frontiers Editorial Office,

Frontiers Media SA, Switzerland

*Correspondence:

Stuart A. Newman

newman@nymc.edu

Specialty section

This article was submitted to Integrative Physiology, a section of the journal Frontiers in Physiology

Received: 01 November 2019

Accepted: 04 November 2019

Published: 03 December 2019

Citation:

Newman SA (2019) Corrigendum: Inherency of Form and Function in Animal Development and Evolution.

Front. Physiol. 10:1433.

doi: 10.3389/fphys.2019.01433

\section{Corrigendum: Inherency of Form and Function in Animal Development and Evolution}

\author{
Stuart A. Newman* \\ Department of Cell Biology and Anatomy, New York Medical College, Valhalla, NY, United States
}

Keywords: biogeneric, morphogenesis, pattern formation, cell differentiation, self-organization, phase transition, reaction-diffusion

\section{A Corrigendum on}

Inherency of Form and Function in Animal Development and Evolution by Newman, S. A. (2019). Front. Physiol. 10:702. doi: 10.3389/fphys.2019.00702

In the original article, there was a mistake in Table $\mathbf{1}$ as published. Because of an editing error, the lines for "Apicobasal cell polarization" and "Nonliquid cellular assemblages via matrices" were transposed. The corrected Table 1 appears below.

The author apologizes for this error and states that this does not change the scientific conclusions of the article in any way. The original article has been updated.

\footnotetext{
Copyright (c) 2019 Newman. This is an open-access article distributed under the terms of the Creative Commons Attribution License (CC BY). The use, distribution or reproduction in other forums is permitted, provided the original author(s) and the copyright owner(s) are credited and that the original publication in this journal is cited, in accordance with accepted academic
} practice. No use, distribution or reproduction is permitted which does not comply with these terms. 
TABLE 1 | Novel inherent properties in animal development and evolution.

\section{Property}

1. Properties dependent on novel genes or regulatory motifs coincident with emergence of Metazoa

Liquid-tissue state

Regulated cell polarity

Capacity to exaggerate intrinsic cell functions

Morphogen gradients

2. Properties dependent on novel genes acquired after metazoan origins Liquid-crystalline-tissue state

Wettable substrata (basal lamina)

Lateral inhibition; oscillation of gene expression

Multiple alternative cell types

3. Properties dependent on ancestral genes repurposed into DPMs in the multicellular context

Cell-cell cohesion in liquid tissues

Apicobasal cell polarization

Nonliquid cellular assemblages via matrices

Cell-cell electrical coupling

Gene or molecular motif

Classical cadherins

Wnt

Enhancers; PcGl proteins

Hedgehog, BMPs

Vang/Stbm

Peroxidasin

Notch, Hes1

MyoD, PPARy, SMAD

\section{Grainyhead}

$\beta$-catenin

Collagen IV

Voltage-gated channels
Character

Multicellularity; layering

Lumens; elongated tissues

Differentiation

Simple cell patterns

Tissue elongation

Appendages, glands

Complex cell patterns

Complex tissues, organs

E-M transformation

Epithelia and lumens

Mesenchymal tissues

Bioelectrical integration

Each list is nonexhaustive but contains the most important examples of its respective category. 